Abstracta Iranica Abstracta Iranica

Revue bibliographique pour le domaine irano-aryen

Volume 26 | 2005

Comptes rendus des publications de 2003

\title{
«Le monnayage du roi sassanide Shapur Ier (240-271) : vers une typologie ». BSFN 58,1 (2003), pp. 4-8.
}

Karin Mosig-Walburg

\section{(2) OpenEdition Journals}

Édition électronique

URL : http://journals.openedition.org/abstractairanica/3465

DOI : 10.4000/abstractairanica.3465

ISSN : 1961-960X

Éditeur :

CNRS (UMR 7528 Mondes iraniens et indiens), Éditions de l'IFRI

\section{Édition imprimée}

Date de publication : 15 mai 2005

ISSN : 0240-8910

Référence électronique

Karin Mosig-Walburg, « « Le monnayage du roi sassanide Shapur ler (240-271) : vers une typologie ». BSFN 58,1 (2003), pp. 4-8. », Abstracta Iranica [En ligne], Volume 26 | 2005, document 157, mis en ligne le 08 décembre 2005, consulté le 25 septembre 2020. URL : http://journals.openedition.org/ abstractairanica/3465 ; DOI : https://doi.org/10.4000/abstractairanica.3465

Ce document a été généré automatiquement le 25 septembre 2020.

Tous droits réservés 
«Le monnayage du roi sassanide Shapur Ier (240-271) : vers une typologie ». BSFN 58,1 (2003),

pp. 4-8.

Karin Mosig-Walburg

1 Présentation du procédé méthodique suivi pour établir une typologie stylistique du monnayage de Šāpūr ${ }^{\text {er }}$ au cours de la préparation du premier volume du Sylloge Nummorum Sasanidarum.

INDEX

Thèmes : 3.2.3. Séleucides, Parthes et Sassanides

\section{AUTEURS}

KARIN MOSIG-WALBURG

Université de Francfort 